International Journal of English Literature and Social Sciences
Vol-7, Issue-1; Jan-Feb, 2022
Journal Home Page Available: https://ijels.com/
Journal DOI: $10.22161 /$ ijels

\title{
Humanistic Concerns in the poem Song of Myself by Walt Whitman
}

\author{
Nisha Rakwal
}

TGT(English) JNV Ramban Jammu and Kashmir, India

Received: 25 Nov 2021; Received in revised form: 10 Jan 2022; Accepted: 17 Jan 2022; Available online: 23 Jan 2022

(C)2022 The Author(s). Published by Infogain Publication. This is an open access article under the CC BY license

(https://creativecommons.org/licenses/by/4.0/).

\begin{abstract}
This research paper talks about the concept of Humanism that is found in the works of Walt Whitman. Song of Myself exposes Whitman's view of the human being. He recognized humanity as embracing many polarities, consisting of cultural, spiritual as well as biological. He also emphasizes on the ethos of equality in America. He believed that humanism is the only way of living our lives and all humans should be treated as equals and children of same God.

Whitman considered life and all of its components special in their own ways and thought of them as perfect whatever they were and wherever they were. He stresses on the individuality and says that an individual should live with an open mind; should have willingness to love others; and should remain non-judgmental. The humanism of Whitman bases itself on their extreme faith in the Almighty. This paper aims at discussing the humanistic concerns in the poem Song of Myself.
\end{abstract}

Keywords—humanism, transcendentalism, spirituality, mysticism and Over-soul.

\section{INTRODUCTION}

The concept of humanism is profoundly ingrained in the works of Whitman. Although to define humanism is not easy yet many theorists and critics have attempted to do this. There are diverse connotations of this term. The basic definition of humanism is to take care of the human demands, needs, desires and the main concern is to give humans a special place in the universe on account of their abilities and faculties. The humanists for centuries have been concerned about the cultivation of human capabilities and to study the products of human endeavors in art and literature. Many philosophers have tried their level best to explain the very nature of human existence. It could be started from an allusion to the famous Greek philosopher Protagoras whose dictum "Man is the measure of all things" had created controversy during his time.

W.T Stance interprets the above dictum as follows: “ 'Man is the measure of all things'; certainly but man as a rational being, not man as a bundle of particular sensations, subjective impressions, impulses, irrational prejudices, self-will, mere eccentricities, oddities, foibles, and fancies" (W.T stance 123).

In simpler terms the dictum agrees to the fact that there is no distinction between sense and reason. Each individual has the ability to distinguish between good and bad, so each person becomes a moral self. Here 'moral' is not used in the sense of following defined set of religious beliefs rather it refers to a more universal concept of morality that strengthens the faith that all people have an intrinsic worth. Thus the Protagoras philosophy sowed the seeds of humanism which would grow into a huge tree with numerous interpretations and assumptions.

Another Greek philosopher, Socrates, was also a great humanist and interpreted humanism through his axiom "know thyself". He prophesized the philosophy of conjoining man with the eternal through the right knowledge which is virtue. Socrates placed virtue, knowledge and human happiness at the same pedestral 
and the reason behind this is that right knowledge in particular ought to lead man to perform right action which ultimately leads to immense happiness. Hence he stressed on self-actualization and self- realization.

Plato's ideas of humanism advocate the establishment of balance between reason, spirit and desire. He seeks to create a better self and proclaims that humans could achieve virtue by acquiring greater capacity for wisdom and rationality. Thus both Plato and Socrates have concern for the well-being of humans. Their teachings were followed by Aristotle, according to whom reason becomes man's highest attribute and his glory as well. He emphasized the study of human virtue and asserted that man must not be viewed as an angel or devil but as a human being. This could be directly related to what Whitman said that He did not belong to the goodness only but also to the wickedness. Hershell Baker comments on Aristotle remarks and says: "His (Aristotle's) is the most urbane kind of humanism, one that candidly names as its object an attainable good" (Hershell Baker 63). Hershell Baker sums up the Greek view of Humanism in the same book in these words: "To understand his own morphology as well as that of the universe is man's highest function and leads to the state of well-being which is virtue. This is the apogee of humanism which for the Greek was an attitude and habit of mind rather than a philosophical system or cult." (104)

In the ancient Greek literature the strain of humanism is prominent and can be seen in work like Sophocle's Oedipus Rex where the protagonist struggles against the inevitable cosmic forces but does not lose heart. This shows that Greek humanism had profound respect for mankind and it could be justified by Sophoclean adage: "Wonders are many and none is more wonderful than man." Similarly, the works of Whitman propound the fact that man should be placed as the highest because of the greatest virtue possessed by him which is reason. The rediscovery of humanistic values in Greek works during the $14 \mathrm{C}$ which tried to define humanism is often referred to as Renaissance humanism. In the classics of Greek literature man was glorified. During this age man tried to make his earthly life a joyful experience instead of worrying about death.

In Christianity, humanism dwells on the changeover from scientific questions to the problems of moral life and religious imagination. Erasmus, the prince of the modern humanists, emphasized on the dignity of man through Christ's atonement and God's grace. In Praise of Folly, he criticized the corruption in the Church and insisted on the understanding of life. He also argued that true Christianity should free itself from superstitions and dogmas of the society.

F.C.S. Schiller, a modern humanist, branded pragmatism as humanism. He emphasized that the highest task of the pragmatic humanism is the service of man. In the contemporary world naturalistic humanism has become popular which is also called as scientific humanism. This kind of humanism is against the existence of God and rejects the illusion of immortality. This philosophy holds that there is no supernatural being and man is a wholly natural being whose well-being rests on his own efforts, not guided by any transcendent support.

When we consider humanism in India, it is observed that various religions propound the idea of universal humanity like Sikhism, Buddhism, Hinduism, Islam through the Saints and Bauls as their mouthpiece. For instance, Raja Ram Mohan Roy pleads for having a universal religion to be embraced by the whole mankind. Mahatma Gandhi dedicated his life for the cause of the downtrodden. Also, in the ancient Indian scriptures like Bhagvad-Gita it is mentioned that "....I am the life in all beings..." (Bhagavad-Gita 7-9). Here, the emphasis is given to the mankind and God can be found in the inner self of man. Therefore, through the above discussions it can be asserted that the central concern of humanism is man. Humanism opposes:

Naturalism and absolutism, accepting human experience as the primary concern for all. It rejects transcendence of the real, but it is not skeptic like absolutism which considers that truth is unattainable to man. It believes that what is real is attainable and knowable for man; thus rejecting skepticism and agnosticism.

Humanism believes that man is an evolutionary product of nature and a part of it, but his spirit is free. It believes in freedom of man and rejects all kinds of determinism and fatalism. Man possesses genuine freedom of creative choice and action and, therefore, he is the maker of his own destiny. It believes in ethics and morality that grounds all human values in earthly experience and relationship. The position of man as a moral and spiritual subject gains significance in humanism. It assumes a quest for a just society which is above all communalism, sectarianism and other ideas of narrowness. Though humanism 
rejects authority, sacrificial cult of ritualism and theology, it is not antireligion in character. It is religious because it does not reject values and morality in man's life. (Nilesh Arvind Tare 109).

The principles discussed above are the basic criteria for explaining the humanistic concerns in Whitman.

As far as Walt Whitman is concerned, he is his own prophet and the "true son of God". He has been influenced by many religions like Quakerism, Christianity, Hinduism but he was not a follower of any of them. His true religion was humanism. He was an intellectual and a highly unorthodox poet.

Walt Whitman was a conscious artist and a profound original thinker. At the outset of his career he was considered a revolutionary poet who believed that poetry has a function to perform, a mission to pursue. His view on poetry and poets has been repeatedly explained by him in a number of passages in his preface and many of his prose works. He was to write a new kind of poetry for the new world and this should be new in every way in subject matter, in form, in spirit, in its message, and in its style and diction. He wanted to break away from the European style of writing. His innumerable attacks on Shakespeare and 'other feudal' poets of Europe are well known. Although he recognized the importance of 'past' yet the dislike for European traditions continued to the end of his life. He did not want anything from Europe to be repeated in America.

Whitman tried his best to create the new taste in his works and succeeded to a large extent in his effort. In his treatise A Backward Glance O'er Travel'd Road, he has explained his attitude towards poetry which in not a pure art, but an art with a purpose. He asks his readers not to consider Leaves of Grass as a mere literary work rather try to comprehend the meaning behind it. Whitman's theory of poetry shows two voices- the voice of the inspired Romantic critic for whom poetry is a divine gift for spiritual development, and the voice of the utilitarian for whom poetry is an instrument of social and political reform. According to Whitman a poet should incorporate the following tenets as defined in his preface of Leaves of Grass (1855):

The greatest poet hardly knows pettiness or triviality. If he breathes into anything that was before thought small it dilates with the grandeur and life of the universe. $\mathrm{He}$ is a seer... he is individual... he is complete in himself.

(CRE 713)
The most striking feature of Whitman's poetry is his love for the average. His poetry consists of "everyday" life written for the common reader. Whitman's poetry is mystical in approach but his mysticism is not derived from the saints who appear to be completely disgusted with the world of senses. Rather Whitman believed in transcendental form of mysticism and like Tagore makes man the center of his poetic world. He believes that there is no God more divine than humans and also stresses on the equality of man and woman, black and white etc. Although in his prose and poems he refers to "God", "identity", "soul", "self" and similar terms used by mystics, yet his essential efforts is to make the natural supernatural and not vice-versa. In one of his notes he wrote:

"There is nothing in the universe any more divine than man. All gathers to the worship of man- How awful, how beautiful a being-How full of Gods is the world".

Walt Whitman seems to incorporate the Upanishadic view regarding the knowledge of self and love for mankind. His poems explicit the essential nature of man which is pure being, pure conscious and bliss. His knowledge of self is revealed by the following lines:

It is time to explain myself-let us stand up! Here he calling us to realize ourselves. One of the nation of many nations, the smallest the same and the largest the same.

A Southerner as soon as a Northerner, a planter nonchalant and hospitable down by the Oconee I live.

A Yankee bound my own way ready for trade, my joints the limberest joints on earth

And the sternest joints on earth,

A Kentuckian walking the vale of the Elkhorn in my deerskin leggings, a Louisianian

Or Georgian,... (16:5-8)

Here Whitman is meditating on the American self as a universal entity and is capable of assuming any guise without losing its essence. In other words, one must to realize oneself and merge it into Divine without losing its own characteristics. Whitman, in the above lines, treats Americans as containing multitudinous nature of the self. The poet further says that he is not of one nation but belongs to all other nations. He is of the east and of the west; of north and of south; of the city as well as the 
countryside. It means that he belongs to the whole universe. Therefore, it can be concluded that the sixteenth section of Song of Myself exposes Whitman's view of the human being. He recognized humanity as embracing many polarities, consisting of cultural, spiritual as well as biological. He also emphasizes on the ethos of equality in America.

Whitman considered life and all of its components special in their own ways and thought of them as perfect whatever they were and wherever they were. He stresses on the individuality and says that an individual should live with an open mind; should have willingness to love others; and should remain non-judgmental.

In the last lines of the section 23 , poet calls for a revolt against orthodoxy and conservatism and thus argues for the spiritual freedom of the man. Here, he urges the individual to think with an open mind:

$[\ldots]$ this is the lexicographer, this the chemist, this made a grammar of the old cartouches,

These Mariners put the ship through dangerous unknown seas. This is the geologist, this works with the scalpel, and this is a mathematician. Gentleman, to you the first honors always!

Your facts are useful, and they are not my dwelling,

I but enter by them to an area of my dwelling.

Less the reminders of properties told my words,

And more the reminders they of life untold, and of freedom and extrication.

And make short account of neuters and geldings, and favour men and women fully equipt,

And beat the gong of revolt, and stop with fugitives and them that plot and conspire". (23: 51-52)

In the above passage, the poet expresses his happiness over the work done by the scientists and praises them a lot. But reality and materialism is not the end of human life, there is lot more to be done and the physical body is only the way to prepare for the realization of God. The poet argues that he would use science to achieve a better and fuller life for the soul. He longs for the eternal, who lies beyond and there lies the real dwelling of man. This is the 'life untold' which becomes the real concern of the poet. The poet further points out the main hurdle that comes in the way of spirituality that is the enslavement of man by traditions custom and orthodox conventions. So, the poet calls for a free atmosphere so that man may realize his self and try to achieve union with the divine.

While analyzing the views of Humanism as comprehended by Whitman we arrive at an understanding that he displayed universal outlook which embraces the whole mankind, transcending all the barriers. Whitman prophesizes that God - Man axis would be replaced by Man - God axis because of this democratic faith. He believes that humanity should be elevated to the pedestral of divinity. Whitman sees God in Man. He writes:

In the faces of men and women I see God, and in my own face in the glass,

I find letters from God dropt in the strict, and everyone is signed by God's name.(48: 87)

Therefore, the humanism of Whitman bases itself on their extreme faith in the Almighty.

Walt Whitman does not differentiate between good and evil. He also feels the pain and suffering of poor, criminals and slaves alike. He identifies himself with all of these and claims that:

I am not the poet of goodness only. I do not decline to be the poet of wickedness also.

What blurt is this about virtue and about vice? Evil propels me and reform of evil propels me, I stand indifferent.

My gait is no fault-finder's or rejecter's gait.

I moisten the roots of all that has grown.

The lines written above reveal the Whitman's idea of social equality which never secludes any human being irrespective of colour, creed, social status and deeds. Whitman argues that he is non-judgemental and does not consider himself an authority to judge about the virtues or faults in the nature of human being. In the same line of thought Whitman says:

Undrape! you are not guilty to me, or stale nor discarded, I see through the broadcloth and gingham whether or not, And am around tenacious, acquisitive, tireless, and cannot be shaken away.(7: 35)

Whitman becomes a mere spectator, and comments that he does not find anyone 'guilty' or degraded and treats all as equals. The ' $\mathrm{I}$ ' in this section is 
the transcendent soul or the 'Over-soul' who is witness to all that goes on in the world, both good and evil. However, the detachment of the poet is partial because he does not believe in withdrawal from worldly objects rather identifies him with them. In other words it can be said that Whitman believes that the goodness persists in the mankind and eulogize it to the highest level. It is pertinent to mention here that Whitman refers to wickedness as well and does not want to leave it out.

Whitman's humanism is also spiritual in approach. His poetry contains new elements though he was influenced by great writers such as Homer, Shakespeare and even his contemporaries like Carlyle and Coleridge and most significantly by Emerson. These writers introduced him to ancient and modern mystics beginning with Plato and Plotinus. The emphasis on German Transcendentalism in the works of Coleridge and Carlyle must surely have shaped Whitman's mind. Because of these influences his humanism gives the message of hope, cheerfulness, joy and courage. Whitman never complains of anything in his poetry but occasionally, he seems to imply that the world of the senses is not the real world at all; it is only a poor substitute for the Real, the Ideal, the Transcendental. He says: "What is a man anyhow? What am I? What are you'? Whitman's humanism can be explained by the following line taken from his Preface: ".... there is anything in the known universe more divine then men and women". In these lines Whitman simply elevates men and women to the level of divinity.

The Song of Myself depicts the concept of 'Over-soul' and its relation to the soul of man. Whitman writes:

Swiftly arose and spread around me the peace and knowledge that pass all the argument of the earth,

And I know that the hand of God is the promise of my own,

And I Know that the spirit of God is the brother of my own,

And that all the men ever born are also my brothers, and the women my sisters and lovers,

And that a Kelson of the creation is love,

And limitless are leaves stiff or dropping

in the fields,

And brown ants in the little wells

beneath them,
And mossy scabs of the worm fence, heap'd stones, elder, mullein and pokeweed. (5: 33)

In these lines Whitman talks about the result of the mystical union of soul with the 'Over-soul' that leads to peace, knowledge and wisdom, far greater than any knowledge or bliss. At this point of time, the poet realizes that all the creations of God are equally sacred and contain the same life-force. Here the poet is seen as a firm believer of universal camaraderie because he realizes that all men are his brothers and all women are either his sisters or beloveds, and all of them are part of the one 'Supreme Soul'. Whitman maintains that all the creations of the universe whether significant or insignificant, holy or unholy, good or bad are equally valuable. This discussion reveals that Whitman was a humanistic who treated all mankind as equal and claimed that the Divine Soul holds them together.

Whitman also talks about acquiring true knowledge and wisdom through the course of mystical journey. Whitman stresses upon man's communion with nature for the eventual happiness of all mankind. Whitman says:

Have you reckon'd a thousand acres much? Have you recokon'd the earth much?

Have you practis'd so long to learn to read?

Have you felt so proud to get at the meaning of poems? Stop this day and night with me and you shall possess the origin all poems.

You shall possess the good of the earth and sun, (there are millions of suns left,)

You shall no longer take things at second or third hand, nor look through the eyes of the dead, nor feed on the spectres in books,

You shall not look through my eyes either, nor take things from me,

You shall listen to all sides and filter them from yourself." (2: 30)

These lines amply establish Whitman as one who urges men to step beyond the knowledge acquired by senses. As a mystic, he emphasizes the significance of intuitive power as an ultimate source of knowledge. Whitman's Song of Myself offers a perceptive commentary on innumerable day to day activities of every man, glimpses of his everyday life which enable the poet to see 
and comprehend the meaning of life and see it as a whole. The poet believes that he is not rooted to any particular place on the earth. He belongs to everybody and to every place. $\mathrm{He}$ is as much as of the sky as of the earth. He embraces all the people on this earth irrespective of gender, age, color or nationality. He stresses on the immortality of the human soul and says that the humans will never die or degrade, although they are unaware of this fact. They are also immortal like the poet but they do not realize this truth. In another section of the poem Song of Myself, the poet emphasizes the fact that his self expands till it embraces the whole humanity. The following lines tend to show the immense diversity that the poet's self attains:

And these tend inward to me, and I tend outward to them, and such as it is to be of these more or less I am, And of these one and all I weave the song of myself $(15: 44)$

Whitman as a poet sequesters himself into all the objects around him and absorbs everything into himself. The resultant is the poem that becomes an offer at the altar of the divine:

In me the caresser of life wherever moving, backward as well as forward sluing,

To riches aside and junior bending, not a person, or object missing,

song. (13: 40)

Absorbing all to myself and for this

Walt Whitman, in this regard, says that all things are a part of God and, therefore, in his philosophy love for mankind is fundamentally the love for God. Whitman's cosmic consciousness embraces matter and spirit into one entity. He believes to surrender to the senses and to celebrate them. The following lines echo this thought of Whitman:

I am the poet of the Body and I am the poet of the Soul,

The pleasures of heaven are with me and pains of hell are with me,

The first I graft and increase upon myself, the latter I translate into a new tongue. $(21: 48)$

Here, the poet sings the praise of the body and the soul. He believes that both soul and body are at the same level, i.e., equally pure and holy. He says that both pleasure and pain are within him. In the same line of thought, the poet further says:
Agonies are one of my changes of garments,

I do not ask the wounded person how he feels; I myself become the wounded person,

My hurts turn livid upon me as I lean on a cane and observe. (33:67)

In these lines the Poet identifies himself with the suffering and the needy. He himself becomes the sufferer.

To conclude it can be observed that Whitman viewed humanity as the divine manifestation of God. According to him the whole world is considered as a manifestation of God, not divorced, but intimately connected with Him. Therefore, it could also be concluded that everything is contained and related to Him. He shows firm faith in God and believes in the conviction that God is the preserver and creator as well as the giver of pain and death. The humanism of Whitman is not about preaching like a priest or theorizing about the relationship of man and God, but simply a practical way to life.

\section{REFERENCES}

[1] Abrams, M. H. A Glossary of Literary Terms. $5^{\text {th }}$ ed. New Delhi: Wadsworth, 2005. Print.

[2] Allen, Gay Wilson. The Solitary Singer. New York: Macmillan, 1955. Print.

[3] Walt Whitman Abroad.Syracause: Syracause University, 1955. Print.

[4] Walt Whitman Handbook. Chicago: Packward, 1946. Print.

[5] Brasas, Juan A. Herrero. Walt Whitman's Mystical Ethics Of Comradeship. New York: State University of New York, 2010. Print.

[6] Bucke, R.M. Cosmic Consciousness. New York: Dutton, 1901. Print.

[7] Bucke, Richard. The Complete Writings of Walt Whitman. New York: G.P. Putnam, 1902. Print.

[8] Carpenter, Edward. Days With Walt Whitman. London: George Allen, 1906. Print.

[9] Chari, V.K. Whitman in The Light Of Vedantic Mysticism. Nebraska: Nebraska University, 1964. Print.

[10] Cuddon, J.A. The Penguin Dictionary Of Literary Terms and Literary Theory. Ed. C.E. Preston. Rev. ed. England: Penguin, 1999. Print.

[11] Daiches, David. Walt Whitman's Philosophy, Literary Essays. New York: Philosophical Library, 1957. Print.

[12] Dhavale, V.N. Walt Whitman. New Delhi: Tata McGrawHill, 1976. Print.

[13] Van Doren, Mark. Walt Whitman, The Poet. Washington D.C.: Library Congress, 1955. Print. 